\title{
EDITORIAL
}

\section{The High Seas 'Commons': Imperative Regulation of Half Our Planet's Surface}

$\Lambda$ fter ten years of deliberations and extremely difficult negotiations, a milestone decision was taken by the United Nations in 1982 when 150 independent nations agreed by consensus on the UN Convention on the Law of the Sea. A further 12 years elapsed before the Convention came into effect on 16 November 1994 with the necessary 60 ratifications. That was a major step forward, inter alia as the oceans and seas together cover more than $70 \%$ of Planet Earth's surface. We now at last have a fairly adequate regime for territorial waters and the new concept of the 200 (nautical) miles-wide 'economic zone', as well as an international governance of the seabed area lying outside the aforementioned 200 nautical miles $(370.4 \mathrm{~km})$.

Be that as it may, a very important piece is largely missing from the comprehensive framework of the Law of the Sea. This most serious gap concerns the legal position of the High Seas lying outside any claimed 200 miles' economic zone of each maritime country. According to the 1982 Law of the Sea Convention and established practice, the High Seas still constitute an international free area or 'commons' that is more or less open to any and every nation or interest for exploitation in any manner that it may desire and be able to develop. The High Seas are, indeed, the last oceanic (and by far the world's biggest if we ignore the atmosphere and outer space) commons to survive relatively unscathed, and it will be a surprise to most of us when we realize that, even after deduction of the 200 miles' economic zone, they still occupy about half of the total surface of our Planet Earth! It is becoming increasingly clear that such areas, for example in the northern Atlantic and along the equatorial Pacific, are very important in the production of 'greenhouse' gases*. So it is our imperative duty to safeguard the High Seas in every possible way - not only for our present and future generations, but also as an integral and very major part of our own and Nature's only habitat, The Biosphere.

Yet the entire future of the High Seas is seemingly very precarious, as with humans becoming more and more pandominant globally, and their populations widely predicted (or at least projected) to continue to build up drastically on land, the time could come when they would find some means of massively invading or otherwise changing the High Seas, and such 'development' must be regulated strictly for the sake of The Biosphere, Humankind, and Nature. The same is true of course of many other uses of the High Seas, and even their traditional employment for transport purposes, weapons' testing, and naval warfare, needs to be supervised concerning such matters as pollution. Moreover there is urgent need of legal control of foreseeable continuing fisheries' and/or other desecration engendering violent counteraction $e . g$. over traditional claims or new ambitions, which counteraction can at present be represented as 'Piracy on the High Seas'. $\dagger$

The main concentrations of living marine resources are, fortunately, within the 200 miles' economic zone and hence remain largely within national jurisdiction. However, the High Seas beyond those legal limits are enormously important per se, comprising as they do a major portion of our Planet's ecological whole, and affecting climate and the production of basic foodstuffs - not to mention minerals, building materials, and fossil fuels, even though these come from the seabed or below.

The undersigned are accordingly convinced (and hereby strongly recommend) that all future use of the resources of the High Seas should be regulated much more closely than is currently practicable for the benefit of Humankind but always with due respect for Nature in order to prevent rapacious overexploitation. Only wise, controlled utilization and development should be permitted anywhere in their vast area.

To date, far too little attention has been given to this quite vital issue. Thus with modern technology, the living marine resources of the High Seas are gradually (or, in the case of some pelagic as well as neritic fishes and mammals, quite drastically) being depleted and risk being exterminated as the necessary legal framework is largely lacking to prevent such tragic misuse of the High Seas. Therefore we urge the UN Conference on Straddling Fish-stocks and Highly Migratory Fish-stocks to enact already this year a treaty requiring an enforceable international law or set of laws that will preserve the living and other resources of the High Seas commons for future generations and hopefully all time.

GUNNAR G. SCHRAM, Emeritus Dean of Law
Professor of International \& Environmental Law
University of Iceland
101 Reykjavik, Iceland,

$\&$

Nicholas Polunin, President

Foundation for Environmental Conservation and of the World Council For The Biosphere.

\footnotetext{
* Our thanks are due to Dr N.V.C. Polunin, of the University of Newcastle upon Tyne, for adding this point and making some other valued suggestions for the improvement of this Editorial. - Ed.

† For an instance that had engendered such a charge from the European Union, see the Canadian official Statement published (after sanctioned editing into the style of our Journal) on page 77 of this issue. It is, however, gratifying to note that, following the subsequent reaching of transatlantic agreement, the Spanish Government started disciplining their own fishermen, actually recalling an erring trawler from across the Atlantic Ocean - which augurs well for their future attitude and action. — Ed.
} 